Egyptian Journal of Aquatic Biology \& Fisheries

Zoology Department, Faculty of Science,

Ain Shams University, Cairo, Egypt.

ISSN $1110-6131$

Vol. 24(1): $593-607$ (2020)

www.ejabf.journals.ekb.eg

\title{
Pollution indices and distribution pattern of heavy metals in Qarun Lake water, Egypt
}

\author{
Rehab F. Abd El-Aal ${ }^{1}$, Seliem M. El Sayed ${ }^{1}$, Mohamed S. Attia ${ }^{2}$, \\ Noha S. Donia ${ }^{3}$, Mohamed E. Goher ${ }^{2}$ \\ 1. National Institute of Oceanography and Fisheries (NIOF), Cairo, Egypt \\ 2. Chemistry Department, Faculty of sciences, Ain-Shams University, Cairo, Egypt \\ 3. Institute of Environmental Studies and Researches, Ain-Shams University, Egypt \\ *Corresponding author: smgoher@yahoo.com
}

\section{ARTICLE INFO \\ Article History: \\ Received: Feb. 29, 2020 \\ Accepted: March 4, 2020 \\ Online: March 7, 2020}

\begin{abstract}
Qarun Lake is a remnant of the historic Moreis Lake; it is an enclosed lake receives the water through several drains mainly El-Bats and El-Wadi drains carrying agricultural wastewater mixed with domestic and industrial wastes to the lake, which increases the accumulation of pollutants, in particular, the heavy metals in the lake environment. The present study is concerning the levels, distribution pattern as well as the pollution indices of the heavy metals in Qarun Lake water. The sites facing the inlet of the drain showed the highest contents of the metal, recording 587.55, 59.6, 61.92, 26.98, 50.72 and $3.63 \mu \mathrm{g} / \mathrm{l}$ for Fe, Mn, Zn, $\mathrm{Cu}, \mathrm{Ni}, \mathrm{Cr}, \mathrm{Pb}$ and $\mathrm{Cd}$ respectively. On the other side the, Metal Index (MI) and Pollution Load Index (PLI) denotes that Qarun Lake is suffering from serious metal pollution for the aquatic life utilization because of the huge amount of wastes discharging into the lake which maybe leads to dangerous adverse impacts on the fish and other aquatic organisms. The study recommended that usage of biological and chemical treatment for wastewater discharging into the lake into to improve the water quality of the lake water.
\end{abstract}

\section{INTRODUCTION}

Salt lakes are widespread and occur on all continents and are found under a range of conditions, including cold and hot temperatures. They are, however, mostly confined to semiarid to arid regions where evaporation exceeds precipitation. They generally form the terminus of a closed (endorheic) drainage system, with the balance between hydrological inputs (surface and groundwater flows, and precipitation over the lake) and outputs (evaporation and seepage) allowing the permanent or temporary persistence of a body of water, conditions that most often occur in arid and semiarid regions (Finlayson, 2016). Williams (2005) reports that almost the whole range of pollutants discharged to fresh waters is also discharged to salt lakes or their inflows. This includes sewerage discharges and agricultural runoff, and domestic and industrial garbage that has resulted in pollution by metals, with examples Qarun Lake in Egypt

Nowadays, Qarun Lake suffers from several environmental problems. Many factors affecting Qarun Lake ecosystem include the climatic conditions, amount of 
discharged wastewater, seepage from the surrounding cultivated land and geological aspects (Goher et al. 2018). The increase in salinity depends on the input of drainage water and the subtropical climate of the lake leading to high temperature and seasonal fluctuations in water evaporation rate (Anwar et al. 2001). The Lake receives the agricultural and sewage drainage waters through a system of drains, mainly, El-Bats and El-Wadi drains (Authman and Abbas, 2007 \& El-Shabrawy et al. 2015 ). The Lake received annually about 450 million cubic meters of agricultural drainage water. Due to Qarun Lake is a closed ecosystem, and as a result of, extensive evaporation of water, the accumulation of chemical pollutants (heavy metals, pesticides, and other pollutants) is expected to increase annually in all its components (e.g. water and fish) and to change their quality and affect their aquatic life (Mansour and Sidky, 2003). The quality and quantity of surface water bodies such as lakes depend upon the climate, catchments, geography of the area and the inputs and outputs both natural and manmade (Gray, 1994). The water quality evaluation may be a complicated practice in compound parameters causing numerous anxieties in general quality of water (Bharti et al. 2011).

Heavy metals are present in the environment in different phases such as solid phase and in solution, as free ions, or absorbed to solid colloidal particles. The trace metal levels in the environment are due to natural sources as well as an anthropogenic source such as municipal wastewater, agricultural activities and manufacturing industries (Güven and Akýncý, 2008). Heavy metals consist of essential and nonessential elements that have a particular significance in ecotoxicology because they are highly persistent and all have the potential to be toxic to living organisms (Goher et al. 2019a). Recent years have witnessed significant attention being paid to the problems of environmental contamination by a wide variety of chemical pollutants, including trace metals (Censi et al. 2006). Metals are of particular concern, among environmental pollutants, because of their ability to bioaccumulate in aquatic ecosystems and potential toxic effects (Camusso et al. 1995). The main objective of the current study to assess levels of heavy metals in Qarun Lake water, in addition, to evaluate the impact of the drainage water on the metal pollution in the lake in terms of the Metal Index (MI) and Pollution Load Index (PLI).

\section{MATERIALS AND METHODS}

\section{Study area:}

Qarun Lake is a remnant of "the historic Lake Moeris" (Figure 1) and was originally a fresh water lake. It is a general tank for agricultural wastewater of El Fayoum province. Its surface area is about $243 \mathrm{~km}^{2}$ with an irregular shape of about $40 \mathrm{Km}$ length and $6.7 \mathrm{Km}$ maximum width, mean depth $4 \mathrm{~m}$ and a volume about 1 Billion $\mathrm{m}^{3}$ and it lies in the arid zone, so it is considered as a tropical lake (Shadrin $e t$ al. 2016). The lake is located between longitudes of $30^{\circ} 24^{`} \& 30^{\circ} 49^{`} \mathrm{E}$ and latitude of $29^{\circ} 24^{\prime} \& 29^{\circ} 33^{\prime} \mathrm{N}$ (Ibrahim and Ramzy, 2013); latitudes at 43-44 m below the sea level. 


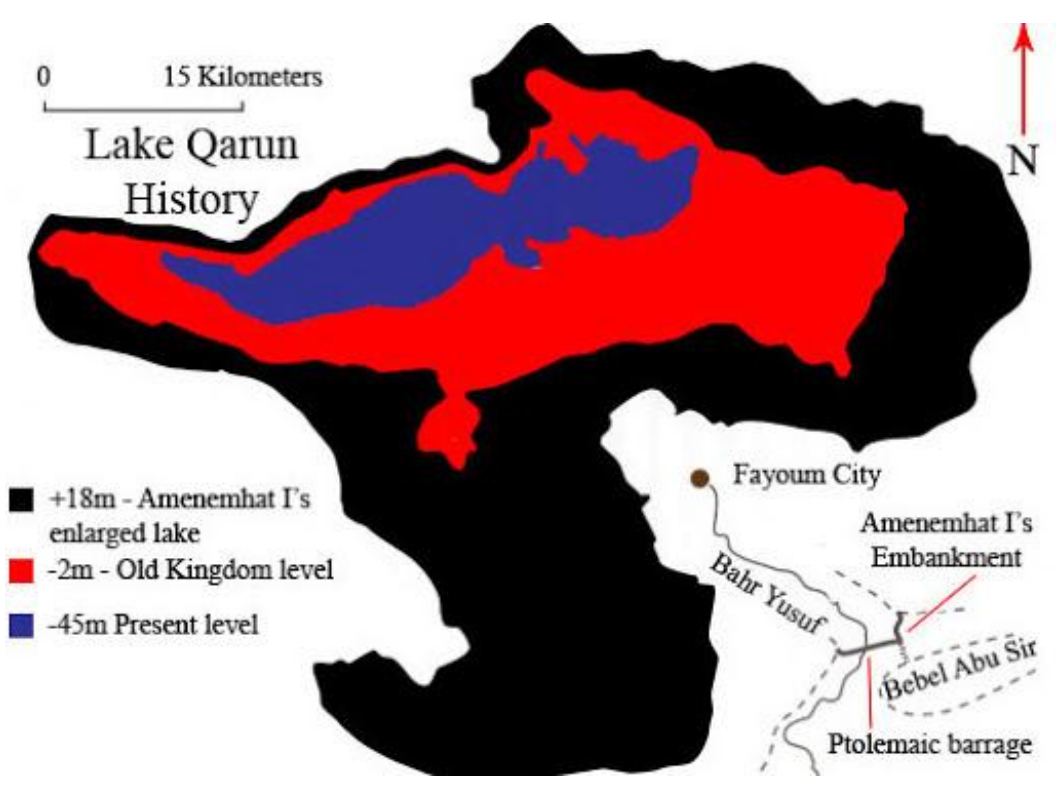

Fig. 1: Long-term changes of Qarun Lake area.

\section{Water sampling:}

Twelve sites were selected to cover the area under investigation beside two main drains; El-Bats and El-Wadi drains (Figure 2 and Table 1)

Table 1: The details of the sampling locations.

\begin{tabular}{|c|c|c|c|}
\hline \multicolumn{4}{|c|}{ Qarun Lake } \\
\hline No. & Name & Latitude & Longitude \\
\hline 1 & In front of the Bats Drain & $29^{\circ} 30 ' 48.03 \prime \prime$ & $30^{\circ} 48^{\prime} 11.16 "$ \\
\hline 2 & $1 \mathrm{~km}$ from the entrance to the Bats Drain & $29^{\circ} 30^{\prime} 14.60^{\prime \prime}$ & $30^{\circ} 48^{\prime} 16.63^{\prime \prime}$ \\
\hline 3 & In front of the Oberge & $29^{\circ} 29^{\prime} 39.37^{\prime \prime}$ & $30^{\circ} 47^{\prime} 7.14^{\prime \prime}$ \\
\hline 4 & In front of the Armed Forces Hotel & $29^{\circ} 29^{\prime} 24.33^{\prime \prime}$ & $30^{\circ} 45^{\prime} 11.84^{\prime \prime}$ \\
\hline 5 & In front of the tongue of Abu Neamah & $29^{\circ} 28 ' 55.91 "$ & $30^{\circ} 42^{\prime} 19.49^{\prime \prime}$ \\
\hline 6 & Khor Mayouf (center of the lake) & $29^{\circ} 28^{\prime} 0.88^{\prime \prime}$ & $30^{\circ} 39^{\prime} 55.83^{\prime \prime}$ \\
\hline 7 & In front of El Wadi Drain & $29^{\circ} 26^{\prime} 38.91 "$ & $30^{\circ} 38 ' 56.47^{\prime \prime}$ \\
\hline 8 & $1 \mathrm{~km}$ from the entrance to El Wadi Drain & $29^{\circ} 26^{\prime} 42.71^{\prime \prime}$ & $30^{\circ} 38^{\prime} 4.34^{\prime \prime}$ \\
\hline 9 & North of EL Karn Island (central lake) & $29^{\circ} 28 ' 46.05 \prime \prime$ & $30^{\circ} 36^{\prime} 34.29 \prime \prime$ \\
\hline 10 & In front of Masr Liltaemir Village & $29^{\circ} 26^{\prime} 35.78^{\prime \prime}$ & $30^{\circ} 33^{\prime} 48.32^{\prime \prime}$ \\
\hline 11 & West of the Lake & $29^{\circ} 25^{\prime} 30.94^{\prime \prime}$ & $30^{\circ} 29^{\prime} 42.77^{\prime \prime}$ \\
\hline 12 & Mizar navigation (Far West) & $29^{\circ} 26^{\prime} 30.06^{\prime \prime}$ & $30^{\circ} 26^{\prime} 16.44^{\prime \prime}$ \\
\hline
\end{tabular}

\section{Methods of analysis:}

$\mathrm{pH}$, Electrical conductivity (EC), and water temperature were measured in-situ using hydro-lab model Orion Research Ion Analyzer 399A, transparency was estimated via the Secchi disk (diameter $30 \mathrm{~cm}$ ). Water samples were kept in 2-L polyethylene bottles in an icebox to analyze later in the laboratory. The methods of water analyses were done according to APHA (2005), Total heavy metals were determined after digestion using the GBC atomic absorption reader model Savant AA-AAS with GF 5000 graphite furnace.

\section{Statistics:}

One-way ANOVA was examined through the Excel-Stat software to analyze the spatial and temporal variations; where $\mathrm{p} \leq 0.05$ and $\mathrm{p} \leq 0.01$ were taken for 
significance and highly significant levels, respectively. The correlations coefficients (r) between the measured parameters were calculated. In addition to the obtained was examined with principal component analysis (PCA) in order to relate the distribution pattern of the heavy metal levels to the physicochemical parameters using XL Stat (2015) program.

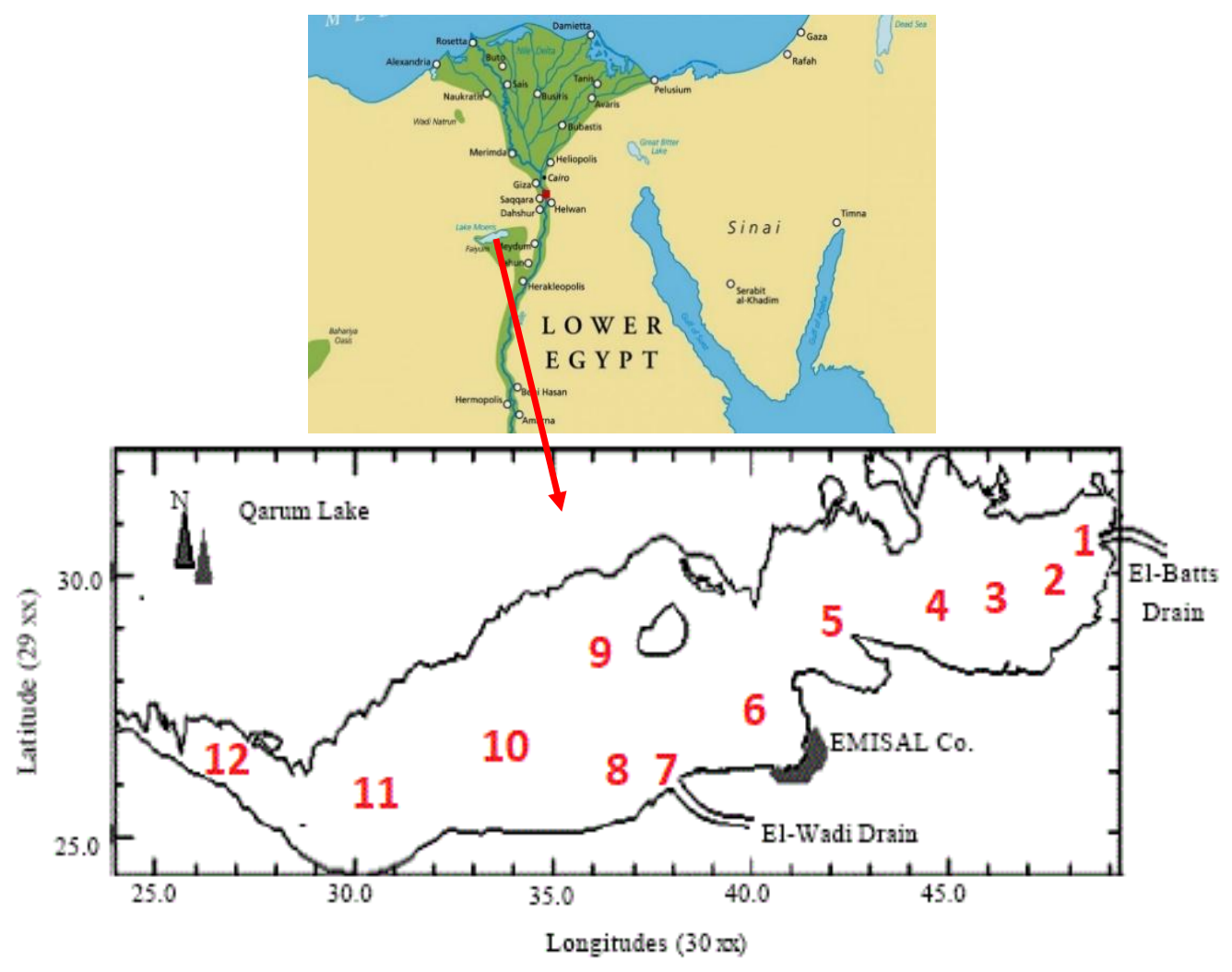

Fig. 2: A map of Qarun Lake showing sampling locations .

Metal Quality indices:

Two different quality indices are used to determine the metal contamination of Qarun Lake water.

Pollution Index (PI):

It is based on individual metal calculations and categorized to 5 classes according to the following equation (Caerio et al. 2005).

$$
P I=\frac{\sqrt{\left[\left(\frac{C i}{S i}\right)_{\max }^{2}+\left(\frac{C i}{S i}\right)_{M i n}^{2}\right]}}{2}
$$

$\mathrm{C}_{\mathrm{i}}$ : the concentration of each element.

$\mathrm{S}_{\mathrm{i}}$ : metal level according to national water quality criterion.

Metal Index (MI):

It is based on a total trend evaluation of the present status. The higher the concentration of a metal compared to its respective MAC value, the worse the quality of the water. MI value $>1$ is a threshold of warning (Bakan et al. 2010). According to (Tamasi and Cini, 2004), the MI is calculated by using the following formula:

$$
M I=\sum_{i=1}^{n} \frac{C i}{(M A C)_{i}}
$$

$\mathrm{C}_{\mathrm{i}}$ : the concentration of each element.

MAC: maximum allowable concentration. 


\section{RESULTS AND DISCUSSION}

\section{Physicochemical characteristics of Qarun water:}

Temperature is an important factor in the aquatic environment. It ranged between $12.80{ }^{\circ} \mathrm{C}$ at site (4) during winter and $29.10^{\circ} \mathrm{C}$ at a site (7) during summer with highly temporal significant difference $(\mathrm{p}<0.01)$. In general, the water temperature in Qarun Lake was suitable for fish habitat and was within the permissible limits $\left(8-28^{\circ} \mathrm{C}\right)$. Qarun Lake is characterized by water turbidity due to the deteriorating effect of El-Bats and El-Wadi drains. Transparency ranged between the lowest value $15 \mathrm{~cm}$ at a site (1) during winter and a site (7) during spring and the highest one $80 \mathrm{~cm}$ at a site (6) during autumn with highly temporal significant difference $(\mathrm{p}<0.01)$. On the other hand, the water of El-Bats and El -Wadi drains were more turbid, where the transparency ranged between $(5-10 \mathrm{~cm})$ and $(10-15 \mathrm{~cm})$, respectively. The total dissolved solids (TDS) changed in a wide range 14.24-39.80 $\mathrm{g} / \mathrm{l}$ with spatial significant difference $(\mathrm{p}<0.01)$. The maximum salinity values have observed at site (12), the most western one, during summer due to temperature elevation and evaporation rate (Goher $\boldsymbol{e t}$ al. 2018). While the sites close to the drains inlet recorded the lowest TDS values due to the dilution effect of the brackish wastewater. TDS in El-Bats and El-Wadi drains water fluctuated between (1.74-3.62) and (1.85-4.82) g/l, respectively (Table 2), which are much, lower than the lake water. The total suspended solids (TSS) changed in a wide range of 13.0-75.12 mg/l with high temporal and spatial significant difference $(\mathrm{p}<0.01)$. TSS in El-Bats and El-Wadi drains water fluctuated between (57.0-89.62) and (45.0-79.64) mg/l, respectively, which are higher than the lake water. TSS levels are higher than those of permissible limits $(25 \mathrm{mg} / \mathrm{l})$ during all seasons.

Table 2: physicochemical parameters of Qarun Lake water compared to Canadian guidelines for aquatic life protection

\begin{tabular}{|c|c|c|c|c|c|c|c|}
\hline parameter & Range & Mean \pm SD & Aquatic life* & parameter & Range & Mean \pm SD & $\begin{array}{l}\text { Aquatic } \\
\text { lifo* }\end{array}$ \\
\hline Temp. $\left({ }^{\circ} \mathrm{C}\right)$ & $12.80-29.10$ & $21.20 \pm 5.18$ & $8-28$ & $\mathrm{pH}$ & $7.91-8.75$ & $8.31 \pm 0.2$ & $6.5-9$ \\
\hline Transparency $(\mathrm{cm})$ & $15.00-80.00$ & $43.96 \pm 11.87$ & & $\mathrm{DO}(\mathrm{mg} / \mathrm{l})$ & $3.60-15.0$ & $7.40 \pm 2.99$ & $>5.5$ \\
\hline Salinity (TDS) (g/l) & $14.24-40.2$ & $33.49 \pm 2.42$ & & $\mathrm{BOD}(\mathrm{mg} / \mathrm{l})$ & $4.05-13.12$ & $6.75 \pm 1.62$ & $<6$ \\
\hline TSS (mg/l) & $13.0-75.12$ & $37.17 \pm 15.46$ & 25 & $\operatorname{COD}(\mathrm{mg} / \mathrm{l})$ & $10.40-35.48$ & $25.33 \pm 7.96$ & \\
\hline
\end{tabular}

$\mathrm{pH}$ of Qarun Lake water lies in the alkaline side and is still in the permissible limits (6.5-9) for the aquatic organisms. The maximum $\mathrm{pH}$ value (8.75) was recorded at sites (3) and (4) during winter, while the minimum $\mathrm{pH}$ (7.91) was recorded at a site (1). ANOVA study shows a spatial significant difference $(\mathrm{p}<0.05)$. Dissolved oxygen (DO), Biological Oxygen Demand (BOD) and Chemical Oxygen Demand (COD) values varied in the ranges of (3.60-15), (4.05-13.12) and (10.40-35.48) $\mathrm{mg} / \mathrm{l}$. with spatial significant difference $(\mathrm{p}<0.01)$. The coefficient correlation data showed that BOD and DO are negatively correlated with temperature $(r=-0.58, \mathrm{P}<0.01)$ and $(\mathrm{r}=-0.75, \mathrm{p}<0.01)$, respectively. However, COD is positively correlated with temperature $(\mathrm{r}=0.62)$. DO is negatively correlated with metals as $\mathrm{Cr}(\mathrm{r}=-0.55), \mathrm{Fe}(\mathrm{r}=-$ $0.48)$ and $\mathrm{Ni}(\mathrm{r}=-0.49)$.

\section{Heavy metals:}

Heavy metals may enter an aquatic ecosystem from different natural and anthropogenic sources, including industrial or domestic sewage, storm runoff, leaching from landfills, shipping and harbor activities and atmospheric deposits (Rajeshkumar and Munuswamy, 2011). 


\section{Iron (Fe):}

Iron is one of the most abundant metals in the earth's crust. The results showed that $\mathrm{Fe}$ fluctuated in the range 158.76-587.55 $\mu \mathrm{g} / \mathrm{l}$ with temporal and spatial significant difference $(\mathrm{p}<0.01)$ (Table 3 ). The highest value of iron concentrations $(587.55 \mu \mathrm{g} / \mathrm{l})$ recorded at a site (1) during summer may be attributed to the dissolution of sediments and the release of iron to the overlying water. The lowest value of iron $(158.76 \mu \mathrm{g} / \mathrm{l})$ was recorded at a site (9) during winter may be due to the oxidation of $\mathrm{Fe}^{+2}$ to $\mathrm{Fe}^{+3}$ and precipitated as hydroxide. These results agreed with (Ibrahim and Ramzy, 2013, Sabae and Mohamed, 2015 and Goher et al. 2019b). Also, Massoud et al. (2005) showed that the increase of heavy metal uptake by phytoplankton due to blooming phenomena during the cold period decrease their levels in the water column. Also, Goher et al. (2019b) reported that the distribution dynamics of iron in the water system depend on the dissolved oxygen and is usually present as insoluble $\mathrm{Fe}(\mathrm{OH})_{3}$ or ferric oxide. The ferrous form can only exist in the absence of oxygen and the ferric form is almost completely insoluble. In other words, at oxygenated water iron is precipitated as ferric form, while in the absence of oxygen and the water containing $\mathrm{CO}_{2}$ comes in contact with iron in the ferrous form, in this case, ferrous bicarbonate goes into solution, however at the oxidation occur insoluble ferric hydroxide ions precipitated as follows:

\section{$4 \mathrm{Fe}\left(\mathrm{HCO}_{3}\right)_{2}+2 \mathrm{H}_{2} \mathrm{O}+\mathrm{O}_{2} \Longleftrightarrow 4 \mathrm{Fe}(\mathrm{OH})_{3}+8 \mathrm{CO}_{2}$}

Also, in water contains ferrous sulfate which is unstable in presence of dissolved oxygen, ferrous sulfate and sulphuric acid (formed by the action of microorganisms) react under the presence of oxygen to produce ferric sulfate, which is quickly hydrolyzed to ferric hydroxide.

$$
\begin{aligned}
& 4 \mathrm{FeSO}_{4}+2 \mathrm{H}_{2} \mathrm{SO}_{4}+\mathrm{O}_{2} \\
& \mathrm{Fe}_{2}\left(\mathrm{SO}_{4}\right)_{3}+6 \mathrm{H}_{2} \mathrm{O}
\end{aligned} \longrightarrow \begin{aligned}
& 2 \mathrm{Fe}_{2}\left(\mathrm{SO}_{4}\right)_{3}+2 \mathrm{H}_{2} \mathrm{O} \\
& 2 \mathrm{Fe}(\mathrm{OH})_{3}+3 \mathrm{H}_{2} \mathrm{SO}_{4}
\end{aligned}
$$

On the other hand, Fe levels in Qarun Lake water were within the permissible level $(300 \mu \mathrm{g} / \mathrm{l}) \mathrm{CCME}(2017)$ around the year except for summer. Fe concentration in El-Bats and El-Wadi drains water ranged between (299.46-614.22) and (313.74501) $\mu \mathrm{g} / \mathrm{l}$, respectively (Table 4). Iron is necessary to photo-synthesizing plants, where it is the metallic part of at least two plant cytochromes; that function in the transfer of electrons during photosynthesis and it is an important trace metal requirement for all biological life. However, at high concentrations, iron (II) is toxic for most organisms that may decrease the species diversity and abundance of periphyton, benthic invertebrates and fishes (Vuori, 1995).

The statistical analysis showed that iron is positively correlated $(\mathrm{P}<0.01)$ with temperature $(\mathrm{r}=0.65), \mathrm{Mn}(\mathrm{r}=0.84), \mathrm{Zn}(\mathrm{r}=0.84), \mathrm{Cu}(\mathrm{r}=0.84), \mathrm{Cr}(\mathrm{r}=0.80), \mathrm{Ni}(\mathrm{r}=$ 0.76), $\mathrm{Pb}(\mathrm{r}=0.86), \mathrm{Cd}(\mathrm{r}=0.80)$ and $\mathrm{COD}(\mathrm{r}=0.36, \mathrm{p}<0.05)$ which indicates their common source. While it is negatively correlated $(\mathrm{p}<0.05)$ with transparency $(\mathrm{r}=-$ $0.33)$, TDS $(\mathrm{r}=-0.33), \mathrm{pH}(\mathrm{r}=0.30)$ and $\mathrm{DO}(\mathrm{r}=-0.48, \mathrm{p}<0.01)$, which may be related to the precipitation of iron into the bottom sediment under the effect of the $\mathrm{pH}$ and DO, these results are in agreement with many studies (Goher, 1998, 2002 \&2019, Abdel Satar et al. 2010 and El Sayed et al. 2015).

\section{Manganese (Mn):}

Manganese, functions as an essential constituent for bone structure, reproduction and normal operation of the enzymes system. They are toxic only when present in a higher amounts, but at low level is considered as micronutrient (ElNaggar et al. 2009). It ranged between (11.31-59.60) $\mu \mathrm{g} / \mathrm{l}$. In similar trend of Iron distribution, the highest values of manganese were recorded during summer that may 
be attributed to the elevation in temperature decreases the assimilation rate by aquatic organism especially macrophytes (Berg et al. 1995) in addition to the release of metals from the sediments due to the bacterial activity and temperature elevation (Goher et al. 2019b). Mn levels are within the permissible level $(50 \mu \mathrm{g} / \mathrm{l})$ along the lake except at site (1) during summer. On the other hand, Mn concentration in El-Bats and El-Wadi drains water in the ranges of (18.88-56.99) and (29.07-43.69) $\mu \mathrm{g} / \mathrm{l}$, respectively. $\mathrm{Mn}$ is positively correlated $(\mathrm{n}=48, \mathrm{p}<0.01)$ with Temperature $(\mathrm{r}=0.55)$ and COD ( $\mathrm{r}=0.34, \mathrm{p}<0.05), \mathrm{Cu}(\mathrm{r}=0.82), \mathrm{Cr}(\mathrm{r}=0.76), \mathrm{Pb}(\mathrm{r}=0.79), \mathrm{Cd}(\mathrm{r}=0.79) \mathrm{Zn}$ $(\mathrm{r}=0.73, \mathrm{p}<0.01)$, and $\mathrm{Ni}(\mathrm{r}=0.77, \mathrm{p}<0.01)$. This result agreed with that reported by Goher (2002). While it is negatively correlated $(n=48, p<0.01)$ with transparency $(r=$ -0.56), TDS $(\mathrm{r}=-0.44)$ and DO $(\mathrm{r}=-0.37)$.

Table 3: Heavy metals levels $(\mu \mathrm{g} / \mathrm{L})$ in Qarun Lake water during the studied period

\begin{tabular}{lllllll}
\hline parameter & Autumn & Winter & Spring & Summer & Mean \pm SD & guidelines \\
$\mathbf{F e}$ & $169.65-313.69$ & $158.76-246.17$ & $223.61-373.98$ & $260.99-587.55$ & $270.82 \pm 80.84$ & 300 \\
$\mathbf{M n}$ & $13.87-38.97$ & $11.31-33.10$ & $20.72-37.65$ & $22.40-59.60$ & $26.44 \pm 6.71$ & 50 \\
$\mathbf{Z n}$ & $13.27-31.74$ & $12.69-23.69$ & $14.60-34.91$ & $34.70-61.92$ & $26.72 \pm 13.53$ & 50 \\
$\mathbf{C u}$ & $1.39-15.35$ & $1.29-8.24$ & $6.15-18.00$ & $5.69-19.85$ & $8.22 \pm 2.94$ & 4 \\
$\mathbf{N i}$ & $4.27-8.44$ & $3.97-7.63$ & $6.18-12.18$ & $7.34-12.82$ & $7.47 \pm 1.89$ & 25 \\
$\mathbf{C r}$ & $6.03-13.62$ & $3.49-9.01$ & $11.03-24.73$ & $13.95-26.98$ & $12.95 \pm 6.80$ & 10 \\
$\mathbf{P b}$ & $17.29-31.19$ & $16.08-25.11$ & $22.68-47.29$ & $29.94-50.27$ & $27.82 \pm 7.21$ & 7 \\
$\mathbf{C d}$ & $0.88-1.61$ & $0.18-1.61$ & $1.55-3.17$ & $1.74-3.63$ & $1.59 \pm 1.08$ & 1 \\
\hline
\end{tabular}

Table 4: Range and annual mean $( \pm$ SD $)$ of heavy metals $(\mu \mathrm{g} / \mathrm{l})$ in El-Bats and El-Wadi drains during (2016-2017).

\begin{tabular}{lcccc}
\hline parameter & \multicolumn{2}{c}{ El -Bats drain } & \multicolumn{2}{c}{ El- Wadi Drain } \\
& Range & Annual Average \pm SD & Range & Annual Average \pm SD \\
\hline Fe & $299.46-614.22$ & $345.21 \pm 143.68$ & $313.74-501.00$ & $352.33 \pm 80.27$ \\
Mn & $18.88-56.99$ & $42.23 \pm 18.14$ & $29.07-43.69$ & $34.73 \pm 6.46$ \\
Zn & $70.71-116.27$ & $77.37 \pm 20.03$ & $61.46-89.16$ & $65.98 \pm 12.02$ \\
Cu & $19.11-34.18$ & $23.16 \pm 7.004$ & $15.62-26.28$ & $19.82 \pm 4.75$ \\
Ni & $15.29-25.24$ & $16.84 \pm 4.54$ & $14.61-24.30$ & $16.33 \pm 4.40$ \\
Cr & $16.32-27.13$ & $21.06 \pm 4.89$ & $16.67-36.04$ & $19.41 \pm 8.97$ \\
Pb & $32.61-65.13$ & $46.97 \pm 13.71$ & $29.15-66.47$ & $42.36 \pm 15.62$ \\
Cd & $2.084-3.200$ & $2.44 \pm 0.57$ & $2.22-4.042$ & $2.93 \pm 0.75$ \\
\hline
\end{tabular}

\section{Zinc (Zn):}

Zinc is known to be one of the most toxic metals to many organisms above certain concentrations and exposure duration (Maity et al. 2008). Zinc may exist in water as the free radicals or as soluble complexes (associated with the soluble chlorides and sulphates), or can be adsorbed on the suspended matter (Authman et al. 2015). While insoluble zinc carbonate, zinc oxide and zinc sulfide precipitate out of solution in most natural waters. In Qarun Lake water, $\mathrm{Zn}$ ranged between 12.69 and $61.92 \mu \mathrm{g} / \mathrm{l}$. The lowest value of zinc $(12.69 \mu \mathrm{g} / \mathrm{l})$ was recorded at site a (12) during winter. While the highest value $(61.92 \mu \mathrm{g} / \mathrm{l})$ was recorded during summer at a site (7) that facing El-Wadi Drain that may be attributed to the decomposition of organic matter particulate by bacterial activities (Hassouna et al. 2019). On the other hand, Zn concentration in El-Bats and El-Wadi drains water ranged between (70.71-116.27) and (61.64-89.16) $\mu \mathrm{g} / \mathrm{l}$, respectively. Zinc is positively correlated $(\mathrm{n}=48, \mathrm{p}<0.01)$ with Temperature $(\mathrm{r}=0.71), \mathrm{Cu}(\mathrm{r}=0.75), \mathrm{Cr}(\mathrm{r}=0.79), \mathrm{Ni}(\mathrm{r}=0.78), \mathrm{Pb}(\mathrm{r}=0.78)$ and Cd $(r=0.74)$. While it is negatively correlated $(n=48, p<0.01)$ with DO $(r=-0.42)$. 


\section{Copper $(\mathbf{C u})$ :}

Copper is a fairly common constituent of natural water. It is a micronutrient fundamental to all forms of life; it may be toxic to organisms by inducing a reduction in enzyme activity or a random rearrangement of structural proteins. The toxicity of copper varied with the chemical characteristics of water as $\mathrm{pH}$, hardness, temperature, dissolved oxygen, alkalinity, and the presence of complexing agents (Goher, 2002). The present results showed that the copper was in the range 1.29-19.85 $\mu \mathrm{g} / \mathrm{l}$. The lowest value was recorded at site (11) during winter, while the highest one was recorded during summer at site (1); infront of the discharge point of El Bats Drain; that may be attributable to the heavy metals released from the sediment to the overlying water under the effect of both high temperature and a fermentation process resulting from the decomposition of organic matter (Goher et al. 2014). In addition to the agricultural runoff and domestic sewage effluents, where domestic sources are the major contributors of copper in the environment. On the other hand, $\mathrm{Cu}$ concentration in El-Bats and El-Wadi drains water ranged between (19.11-34.18) and (15.62-26.28) $\mu \mathrm{g} / \mathrm{l}$, respectively. Copper is positively correlated $(\mathrm{n}=48, \mathrm{p}<0.01)$ with temperature $(\mathrm{r}=0.58), \mathrm{Cr}(\mathrm{r}=0.78), \mathrm{Ni}(\mathrm{r}=0.81), \mathrm{Pb}(\mathrm{r}=0.83), \mathrm{Cd}(\mathrm{r}=0.79)$ and COD $(\mathrm{r}=0.29, \mathrm{p}<$ $0.05)$. While it is negatively correlated $(\mathrm{n}=48, \mathrm{p}<0.01)$ with transparency $(\mathrm{r}=-0.48)$, TDS $(r=-0.42)$ and DO $(r=-0.38)$.

\section{Nickel (NI):}

Nickel is found in natural water in only trace quantities. The toxicity of nickel can be affected by many factors in water such as salinity, dissolved oxygen, hardness, temperature, $\mathrm{pH}$, dissolved solids and alkalinity (Blewett and Leonard EM, 2017). In addition to the adsorbent particles as iron and manganese oxides and organic matter and the sediment texture, (Zhang et al. 2014). Nickel levels in Qarun Lake water ranged between 3.97 and $12.82 \mu \mathrm{g} / \mathrm{l}$ with high temporal significant difference $(\mathrm{p}<$ $0.001)$ and were below the permissible level $(25 \mu \mathrm{g} / \mathrm{l})$ for aquatic life protection. The lowest $\mathrm{Ni}$ value was recorded at site 11 during winter, while the highest value was recorded at a site (1) during summer. On the other hand, Ni concentration in El-Bats and El-Wadi drains water ranged between (15.29-25.24) and (14.61-24.30) $\mu \mathrm{g} / \mathrm{l}$, respectively. The values of nickel concentration in the drains are higher than in Qarun Lake water recording ranges of (15.29-25.24) and (14.61-24.30) $\mu \mathrm{g} / \mathrm{L}$ in El Bats Drain and El Wadi Drain, respectively. Nickel is positively correlated ( $\mathrm{n}=48, \mathrm{p}<$ $0.01)$ with Temperature ( $\mathrm{r}=0.72), \mathrm{Cr}(\mathrm{r}=0.86), \mathrm{Pb}(\mathrm{r}=0.80), \mathrm{Cd}(\mathrm{r}=0.85)$ and COD $(\mathrm{r}=0.36, \mathrm{p}<0.05)$. While it is negatively correlated $(\mathrm{n}=48, \mathrm{p}<0.05)$ with Transparency $(\mathrm{r}=-0.50)$ and DO $(\mathrm{r}=-0.49)$.

\section{Chromiun (Cr):}

Chromium enters natural water through the discharge of industrial wastes, where its salts are used extensively in industrial processes, in electroplating, as a constituent of corrosion-resistant and hardness of steel, in paints, dyes and fungicides and in in leather tanning. So, chromium has a significant constituent of wastewaters, sewage and other refuse, and potentially serious pollutants (Goher, 2002). It ranged between (3.49-26.98) $\mu \mathrm{g} / \mathrm{l}$ with high temporal significant difference $(\mathrm{p}<0.001)$, which were above the permissible level $(10 \mu \mathrm{g} / \mathrm{l})$ during spring and summer. The highest value was recorded at site (1) during summer, while the lowest value was recorded at site (6) during winter that may be related to the uptake of chromium by phytoplankton and the dead phytoplankton settling to the sediment leaving water poor in trace elements (Goher, 2002 and Ali and Abdel-Satar, 2005). Chromium 
concentration in El-Bats and El-Wadi drains are higher than the values of chromium concentration in Qarun Lake water and it ranged between (16.32-27.13) and (16.6736.04) $\mu \mathrm{g} / \mathrm{l}$, respectively. Chromium is positively correlated $(\mathrm{n}=48, \mathrm{p}<0.01)$ with Temperature $(\mathrm{r}=0.81)$, COD $(\mathrm{r}=0.45), \mathrm{Pb}(\mathrm{r}=0.84)$ and $\mathrm{Cd}(\mathrm{r}=0.90)$. While it is negatively correlated $(\mathrm{n}=48, \mathrm{p}<0.01)$ with transparency $(\mathrm{r}=-0.47), \mathrm{DO}(\mathrm{r}=-0.55)$ and BOD $(r=-0.30, p<0.05)$

\section{Lead $(\mathbf{P b})$ :}

Lead is one of these toxic heavy metals largely disseminated in the atmosphere, soils and waters (Eba et al. 2011), It acts by complexing with oxo groups in enzymes and affects virtually all steps in the process of heme synthesis and proline metabolism (Goher, 2002). Lead enters the aquatic environment through lead dust fall out, domestic wastes, leaching of marine paints, erosion and leaching of soil, agricultural discharges and many industrial wastes (Wuana and Okieimen, 2011). It ranged between (16.08-50.27) $\mu \mathrm{g} / \mathrm{l}$ with a high temporal significant difference ( $\mathrm{p}<0.001$ ). Where the host seasons (spring and summer) recorded the high lead levels that may be attributed to the high rate of evaporation as a result of temperature elevation and the heavy agricultural run-off which contains fertilizers, agrochemicals and pesticides (Akan et al. 2012). The lowest value $(16.08 \mu \mathrm{g} / \mathrm{l})$ was recorded at a site (11), while the highest value $(50.27 \mu \mathrm{g} / \mathrm{l})$ was recorded at a site (7). On the other hand, $\mathrm{Pb}$ concentration in El-Bats and El-Wadi drains water ranged between (32.61-65.13) and (29.15-66.47) $\mu \mathrm{g} / \mathrm{l}$, respectively. The obtained results showed that the levels of $\mathrm{Pb}$ in Qarun Lake water were above the permissible level $(7 \mu \mathrm{g} / \mathrm{l})$ for aquatic protection that may be due to agricultural runoff and domestic sewage inflow from the drains. $\mathrm{Pb}$ is positively correlated $(\mathrm{n}=48, \mathrm{p}<0.01)$ with Temperature $(\mathrm{r}=0.69)$, COD $(\mathrm{r}=$ $0.37), \mathrm{Cd}(\mathrm{r}=0.87) . \mathrm{Pb}$ is negatively correlated $(\mathrm{n}=48, \mathrm{p}<0.01)$ with Transparency $(\mathrm{r}=$ $-0.50)$, TDS $(r=-0.44)$ and DO $(r=-0.47)$.

\section{Cadmium (Cd):}

Cadmium is one of the heavy metals, which is highly toxic to humans, plants and animals. Cadmium is a nonessential element that has high toxic potential (Pavan and Benarjee, 2015). Cadmium is an extremely dangerous cumulative toxicant causing insidious progressive chronic poisoning in mammals, fishes and other animals (USEPA, 1979). Regarding the present results, Cd ranged between (0.0183.632) $\mu \mathrm{g} / \mathrm{l}$ with a high temporal significant difference $(\mathrm{p}<0.001)$. The lowest value was recorded at a site (12) during winter, while the highest value was recorded at site a (7) during summer. On the other hand, Cd concentration in El-Bats and El-Wadi drains water ranged between (2.084-3.200) and (2.220-4.042) $\mu \mathrm{g} / \mathrm{l}$, respectively. According to Borg (1984), the heavy metals which have carbonate with low solubility as $\mathrm{Cd} \& \mathrm{~Pb}$ are eliminated from the solution as a result of $\mathrm{CaCO} 3$ co-precipitation. $\mathrm{Cd}$ levels are above the permissible level $(1 \mu \mathrm{g} / \mathrm{l})$ for aquatic life protection recommended by CCME (2017). Cd is positively correlated $(n=48, p<0.01)$ with temperature $(\mathrm{r}=0.77)$, COD $(\mathrm{r}=0.46)$, while it is negatively correlated $(\mathrm{n}=48, \mathrm{p}<$ $0.05)$ with BOD $(r=-0.32)$, TDS $(r=-0.33)$, transparency1 $(r=-0.53, \mathrm{p}<0.01)$ and DO $(\mathrm{r}=-0.57, \mathrm{p}<0.01)$.

In General, the high levels of most heavy metals have existed during the hot seasons in particular during summer, that mainly related to the effect of the high temperature leading to increase of the evaporation rate and decrease the water level, as well as, the release of the metals from the bottom sediment and degradable organic matter under the action of the microbial activity. On the other hand, the sites facing 
the wastes discharge point recorded the high contents of metals in comparison to the other locations, while, the western side (the most far from the drains inlets) showed the lowest values. Figure (3) show the contour map of the heavy metal levels in the lake water

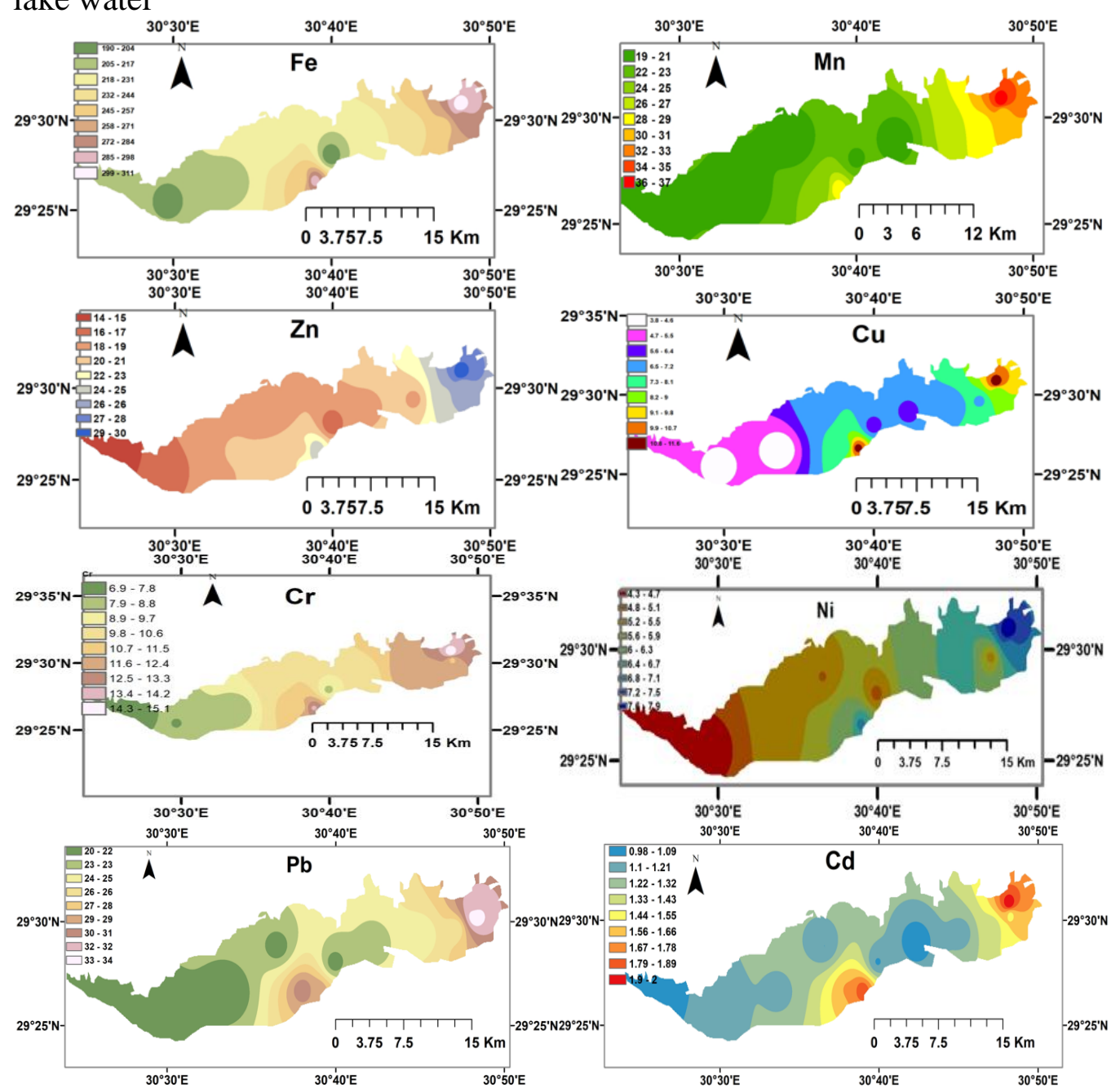

Fig. 3: : Contour map of the annual mean concentration $(\mu \mathrm{g} / \mathrm{l})$ of the studied heavy metals in Qarun Lake water during the study period

\section{Metal Pollution indices:}

Two different indices are designed to evaluate the metal contamination of Qarun Lake water, the first one is the Pollution Index (PI), that independent of the effect of the individual metal. While the other index, Metal index (MI), based on the effect of the level of the total metal. In the present study, the acceptable limits of the trace metals obtained by CCME (Saffran et al. 2001) for aquatic life protection were used as maximum allowable concentration (MAC) value.

\section{Pollution Index (PI):}

The pollution index (PI) was used in our study to determine the grade of trace metals toxicity in water samples. It is based on individual metal calculations and categorized to five classes (Table 5) according to (Caeiro et al. 2005). The results indicate a various pollution degree of the studied metals for aquatic life in Qarun Lake. Pollution index exhibited that $\mathrm{Mn}, \mathrm{Ni}$ and $\mathrm{Zn}$ have not polluted effect for aquatic life usage. On the other hand, $\mathrm{Cd}$ and $\mathrm{Cr}$ showed slight pollution to moderate effect at all sites. Fe showed a slight pollution effect at sites 1, 2, 7 and 8. Cu showed 
slight pollution to strong effects at all sites. Finally, $\mathrm{Pb}$ showed strong pollution to serious effect at all sites (Table 6).

Table 5: Categories of water pollution index.

\begin{tabular}{lll}
\hline Class & PI value & Pollution grade \\
1 & $\leq 1$ & no effect \\
2 & $>1-2$ & slightly affected \\
3 & $>2-3$ & moderately affected \\
4 & $>3-5$ & strongly affected \\
5 & $>5$ & seriously affected \\
\hline
\end{tabular}

Table 6: Pollution index of the measured metals in the Qarun Lake water according to guideline levels of aquatic life utilizations.

\begin{tabular}{|c|c|c|c|c|c|c|c|c|}
\hline \multirow{2}{*}{ Site } & \multicolumn{2}{|c|}{$\mathrm{Fe}$} & \multicolumn{2}{|c|}{$\mathrm{Nn}$} & \multicolumn{2}{|c|}{$\mathrm{Zn}$} & \multicolumn{2}{|c|}{$\mathrm{Cu}$} \\
\hline & PI value & Fffect & PI value & Fffect & PI value & Fffect & PI value & Fffect \\
\hline 1 & 1.50 & Slightly & 0.96 & No & 0.89 & No & 3.80 & Strongly \\
\hline 2 & 1.26 & Slightly & 0.74 & No & 0.81 & No & 2.80 & Moderately \\
\hline 3 & 0.83 & No & 0.64 & No & 0.77 & No & 1.98 & Slightly \\
\hline 4 & 0.88 & No & 0.51 & No & 0.74 & No & 2.13 & Moderately \\
\hline 5 & 0.90 & No & 0.41 & No & 0.56 & No & 1.57 & Slightly \\
\hline 6 & 0.73 & No & 0.45 & No & 0.70 & No & 2.09 & Moderately \\
\hline 7 & 1.37 & Slightly & 0.72 & No & 0.91 & No & 3.57 & Strongly \\
\hline 8 & 1.30 & Slightly & 0.60 & No & 0.72 & No & 2.66 & Moderately \\
\hline 9 & 0.81 & No & 0.47 & No & 0.54 & No & 2.24 & Moderately \\
\hline 10 & 0.77 & No & 0.48 & No & 0.60 & No & 1.76 & Slightly \\
\hline 11 & 0.79 & No & 0.49 & No & 0.55 & No & 1.68 & Slightly \\
\hline 12 & 0.75 & No & 0.45 & No & 0.53 & No & 1.61 & Slightly \\
\hline \multirow{2}{*}{ Site } & \multicolumn{2}{|c|}{$\mathrm{Ni}$} & \multicolumn{2}{|c|}{$\mathrm{Cr}$} & \multicolumn{2}{|c|}{$\mathrm{Pb}$} & \multicolumn{2}{|r|}{$\mathrm{Cd}$} \\
\hline & PI value & Effect & PI value & Effect & PI value & Effect & PI value & Effect \\
\hline 1 & 0.42 & No & 2.01 & Moderately & 5.27 & Seriously & 2.35 & Moderately \\
\hline 2 & 0.34 & No & 1.84 & Slightly & 5.33 & Seriously & 1.88 & Slightly \\
\hline 3 & 0.31 & No & 1.52 & Slightly & 3.95 & Strongly & 1.56 & Slightly \\
\hline 4 & 0.33 & No & 1.55 & Slightly & 3.88 & Strongly & 1.90 & Slightly \\
\hline 5 & 0.31 & No & 1.21 & Slightly & 3.69 & Strongly & 1.28 & Slightly \\
\hline 6 & 0.28 & No & 1.39 & Slightly & 3.82 & Strongly & 1.61 & Slightly \\
\hline 7 & 0.37 & No & 1.81 & Slightly & 5.66 & Seriously & 2.70 & Moderately \\
\hline 8 & 0.31 & No & 1.56 & Slightly & 4.69 & Strongly & 2.08 & Moderately \\
\hline 9 & 0.30 & No & 1.36 & Slightly & 3.59 & Strongly & 1.56 & Slightly \\
\hline 10 & 0.31 & No & 1.05 & Slightly & 3.47 & Strongly & 1.59 & Slightly \\
\hline 11 & 0.29 & No & 1.52 & Slightly & 3.57 & Strongly & 1.39 & Slightly \\
\hline 12 & 0.28 & No & 1.42 & Slightly & 3.60 & Strongly & 1.31 & Slightly \\
\hline
\end{tabular}

\section{Metal Index (MI):}

It is based on a total trend evaluation of the present status. By increasing the concentration of metal compared to its respective maximum allowable value (MAC), the worse impact of the quality of the water appeared. MI value $>1$ is a threshold of warning limit (Cude, 2001). According to MI values, all selected sites in Qarun Lake are suffering from seriously metal pollution for aquatic life utilization. On the other hand, site 1 and 7 are the most sites exposed to metal pollution due to their close to drainage sources (Fig. 4).

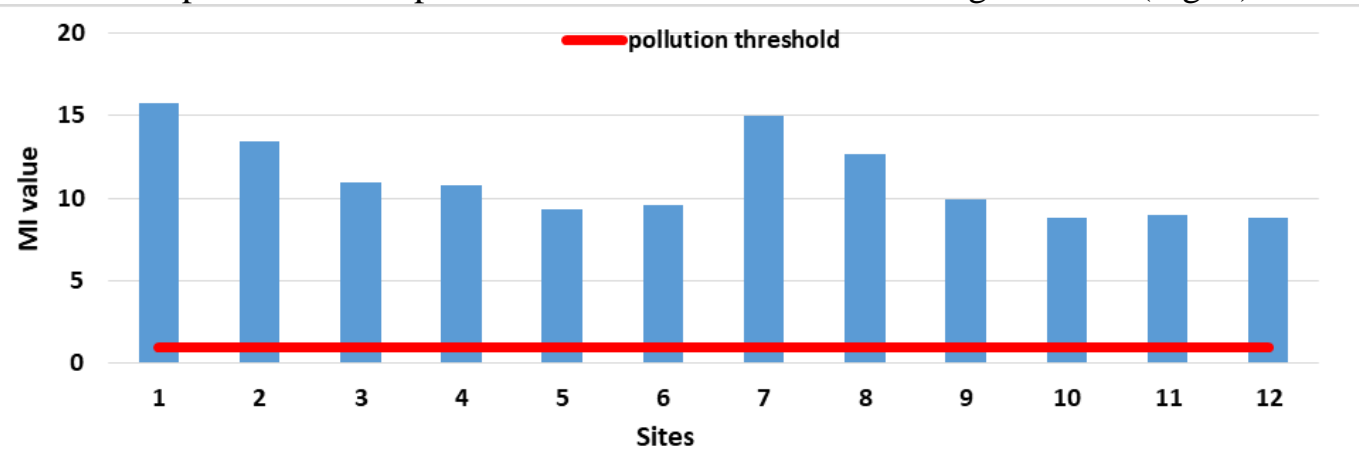

Fig. 4: Metal index of the measured metals in Qarun Lake water for aquatic life utilizations 


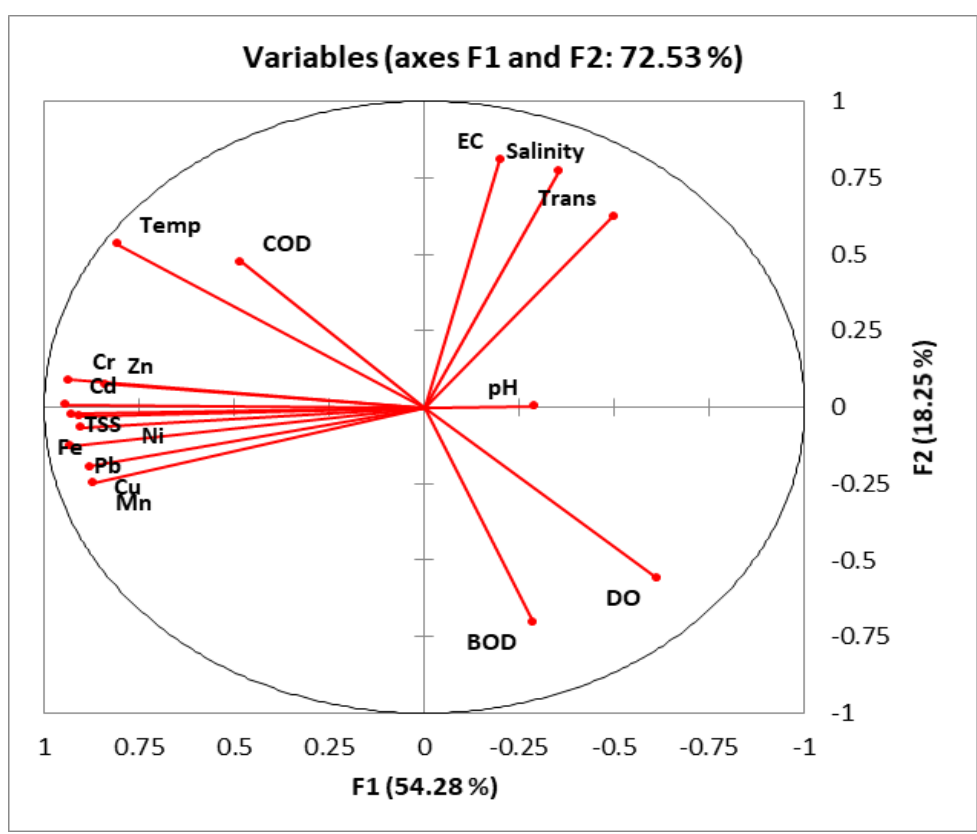

Fig. 5: Principal component analysis (PCA) (Axis I and II) performed on some Heavy metal and some physico-chemical variables

According to Figure (5), the principal component analysis (PCA), heavy metals were positive significantly correlated with each other. That may be attributed to the same allochthonous sources of these metals (the wastes discharged to the lake via the different drains). The first axis explaining $54.28 \%$ of the variables and it was primarily associated with the heavy metals, while axis 2 was explaining $18.25 \%$ of the variance of some physicochemical variables. Also, analysis, showed that all heavy metals closely correlated with COD, TSS and temperature, while negatively with transparency, EC, salinity, $\mathrm{pH}, \mathrm{DO}$ and BOD. PCA showed that $\mathrm{Cr}$ and $\mathrm{Cd}$ were more positively affected by the temperature

\section{CONCLUSION}

Qarun Lake is one of the most important lakes in Egypt; However, it represents as a tank for the discharging agricultural wastewater of El-Fayoum province. Qarun Lake suffers from several environmental pollution problems. This study was carried out to focus on the contents of $\mathrm{Fe}, \mathrm{Mn}, \mathrm{Zn}, \mathrm{Cu}, \mathrm{Ni}, \mathrm{Cr}, \mathrm{Cd}$ and $\mathrm{Pb}$ in Qarun Lake water and their contamination levels using the metal pollution indices. The results showed that the high values of heavy metals in Qarun Lake water have existed during the hot seasons that mainly related to the effect of the high temperature leading to the increase of the evaporation rate and decrease the water level, as well as, the release of the metals from the bottom sediment and degradable organic matter under the action of the microbial activity. On the other hand, the sites opposite the waste discharge points recorded the high contents of metals in comparison to the other locations, while the western side showed the lowest values. In addition, the indices of the metal pollution reveal that Qarun Lake water suffers from a different degree of metal contamination that effect on the water quality, especially for aquatic life utilization

\section{REFERENCES}

Abdel-Satar, A.M.; Goher, M.E. and Sayed, M.F. (2010). Recent Environmental changes in water and sediment quality of Qarun Lake. Egypt. Journal of Fisheries and Aquatic Science, 5 (2): 56 - 69. 
Akan, J.C.; Abbagambo, M.T.; Chellube, Z.M. and Abdulrahman, F.I. (2012). Assessment of Pollutants in Water and Sediment Samples in Lake Chad, Baga, North Eastern Nigeria. Journal of Environmental Protection, 3:1428-1441.

Ali, M.H and Abdel-Satar, A. (2005). Studies of some heavy metals in water, sediment, fish and fish diets in some fish farms in El-Fayoum province. Egyptian Journal of Aquatic Research, 31(2): 261-273.

Anwar, S.M.; El-Shafy, A.A.; El-Serafy, S.S.; Ibrahim, I.I. and Ali, E.A. (2001). Accumulation of Trace Elements in Fish at Qarun Lake as a Biomarker of Environmental Pollution, Journal of the Egyptian German Society of Zoology, 36(A): 443 - 461.

APHA (American Public Health Association), (2005). Standard methods for the examination of water and wastewater. 21th ed., $1015 \mathrm{pp}$, AWWA, WCPF, Washington D.C.

Authman, M.M.N. and Abbas, H. (2007). Accumulation and distribution of copper and zinc in both water and some vital tissues of two fish species (Tilapia and Mugil cephalus) of Qarun Lake, Fayoum Province, Egypt. Pakistan J. of Biologi. Sci., 10(13): 2105 - 2122.

Authman, M.M.N.; Zaki, M.S.; Khallaf, E.A.and Abbas, H.H. (2015) Use of Fish as Bio-indicator of the Effects of Heavy Metals Pollution. J Aquac Res Development 6 (4). doi: 10.4172/2155-9546.1000328

Bakan, G.; Özkoç, H.B.; Tülek, S. and Cüce, H. (2010). Integrated Environmental Quality Assessment of K 1 z 111 rmak River and its Coastal Environment Turkish J. Fish. Aquat. Sci. 462 453-62

Berg, H.; Kiibus, M. and Kautsky, N. (1995). Heavy Metals in Tropical Lake Kariba, Zimbabwe. Water, Air, and Soil Pollution, Vol. 83 (3/4): pp 237-252.

Bharti, N.; Katyal, D., et al.( 2011) Water quality indices used for surface water vulnerability assessment. Int J Environ Sci.; 2(1):154-173.

Blewett, T. A. and Leonard, E. M. (2017). Mechanisms of nickel toxicity to fish and invertebrates in marine and estuarine waters. Environmental Pollution, 223, 311-322. doi.org/10.1016/j.envpol.2017.01.028

Borg, H. (1984). Background of trace elements in Swedish fresh water. The National Environmental Protection Board, pp817.

Caeiro, S.; Costa, M.H.; Ramos, T.B.; Fernandes, F.; Silveira, N.; Coimbra, A.; Medeiros, G and Painho, M. (2005). Assessing heavy metal contamination in Sado Estuary sediment: an index analysis approach Ecol. Indic. 5 151-69

Camusso, M.; Viganoand, L. and Baitstrini, R. (1995). Bioaccumulation of trace metals in rainbow trout. Ecotox Environ Safe 31: 133-141.

CCME (2007). Canadian Council of Ministers of the Environment For the protection of aquatic life 2007. In: Canadian Environmental Quality Guidelines, 1999, Canadian Council of Ministers of the Environment, 1999, Winnipeg.

Censi, P.; Spoto, S.E.; Saiano, F.; Sprovieri, M. and Mazzola, S. (2006). Heavy metals in coastal water systems. A case study from the northwestern Gulf of Thailand. Chemosphere 64: 1167-1176.

Cude, C.G. (2001). Oregon Water Quality Index a Tool for Evaluating Water Quality Management Effectiveness 1 JAWRA J. Am. Water Resour. Assoc. 37 125-37

Eba, F.; Kouya Biboutou, R.; Ndong Nlo, J.; Bibalou, Y.G. and Oyo, M. (2011). Lead removal in aqueous solution by activated carbons prepared from Colas edulis shell (Alocaceae), Penthaclethra macrophylas husk (Mimosaceae) and Aucoumea klaineana sawdust (Burseraceae). African Journal of Environmental Sciences and Technology, 5(3): 197-204. 
El-Naggar, A.M; Mahmoud, S.A. and Tayel, S.I. (2009). Bioaccumulation of some heavy metals and histopathological alterations in liver of Oreochromis niloticus in relation to water quality at different localities along the River Nile, Egypt. World Journal of Fish and Marine Sciences, 1(2): 105-114.

El-Sayed, S.A.; Moussa, E.M.M. and El-Sabagh, M.E.I. (2015). Evaluation of heavy metal content in Qarun Lake, El-Fayoum, Egypt. Part I: Bottom sediments. J. Radiat. Res. Appl. Sci., 8: 276 - 285.

El-Shabrawy, G.M.; Anufriieva, E.V.; Germoush, M.O.; Goher, M.E. and Shadrin, N.V. (2015). Does salinity change determine zooplankton variability in the saline Qarun Lake (Egypt)? Chinese J. Oceanol. Limnol. 33 1368-77

Finlayson, C.M. (2016) Salt Lakes. In: Finlayson C., Milton G., Prentice R., Davidson N. (eds) The Wetland Book. Springer, Dordrecht

Goher, M.E. (1998). Factors affecting the precipitation and dissolution of some chemical elements in River Nile at Damietta Branch, River Nile, Egypt. M.Sc. Thesis, Fac. of Sci., Menofiya Univ., Egypt, 289 p.

Goher, M.E. (2002). Chemical studies on the precipitation and dissolution of some chemical elements in Qarun Lake. Ph.D. Thesis, Faculty of Science, Al-Azhar University, Cairo, Egypt, 278 p.

Goher, M.E.; Ali, M.H.H. and El Sayed, S.M. (2019a). Heavy metals contents in Nasser Lake and the Nile River, Egypt: An overview. Egyptian Journal of Aquatic Research 45: 301-312 https://doi.org/10.1016/j.ejar.2019.12.002

Goher, M.E.; Mahdy, E.M.; Abdo, M.H.; El Dars, F.M.; Korium M.A.and Elsherif, A. S. (2019b). Water quality status and pollution indices of Wadi El-Rayan lakes, El-Fayoum, Egypt. Sustain. Water Resour. Manag. 5, 387-400. https://doi.org/10.1007/s40899-017-

Goher, M.E.; El-Rouby, W.M.A.; El-Dek, S.I.; El-Sayed, S.M. and Noaemy, S.G. (2018). Water quality assessment of Qarun Lake and heavy metals decontamination from its drains using nanocomposites The 4th International Conference on Advanced Applied Sciences IOP Conf. Series: Materials Science and Engineering 464012003.

Goher, M.E.; Hassan, A.M.; Abdel-Moniem, I.A.; Fahmy, A.H and El-sayed, S.M. (2014). Evaluation of surface water quality and heavy metal indices of Ismailia Canal, Nile River, Egypt Egypt. J. Aquat. Res. 40 225-33

Gray, N. F. (1994). Drinking water quality: Problems and solutions. Chichester, UK: John Wiley \& Sons.

Güven, D.E and Akýncý, G. (2008). Heavy metals partitioning in the sediments of Izmir Inner Bay. J Environ Sci (China) 20: 413-418.

Hassouna, E.M., Goher, ME, El-Sayed SM and Hassan, RA (2019) Integrated approach quality indices and health risk assessment for Bahr Yusuf Canal water, Fayoum, Egypt. Oceanological and Hydrobiological Studies Journal. 48(4):337-354 DOI: $10.2478 /$ ohs-2019-0031

Ibrahim, L.A. and Ramzy, E.M. (2013). Water quality and its impact on Tilapia zilli (case study) Qarun Lake-Egypt Int. Water Technol. J. 3 170-91

Maity, S.; Roy, S.; Chaudhury, S. and Bhattacharya, S. (2008). Antioxidant responses of the earthworm Lampito mauritii exposed to $\mathrm{Pb}$ and $\mathrm{Zn}$ contaminated soil. Environmental Pollution, Vol. 151: pp 1-7.

Mansour, S.A. and Sidky, M.M. (2003). Ecotoxicological Studies. 6. The first comparative study between Qarun Lake and Wadi El-Rayan wetland (Egypt), with respect to contamination of their major components. Food Chemistry. 82: $181-189$. 
Massoud, M.S.; Abdel-Samie, A.E.; Alaa, E.A. and Essam, M. (2005): Distribution of some metal concentrations in water and sediment of Lake Edku, Egypt. Chemists and Technologists of Macedonia, 24(1): 21-34.

Pavan, M. and Benarjee G. (2015). studies on physic-chemical parameters and occurrence of heavy metals in an Urban lake of Warangal district during different seasons. International Journal of Plant, Animal and Environmental Sciences. 5 (3): 110-116.

Rajeshkumar, S. and Munuswamy, N. (2011). Impact of metals on histopathology and expresson of HSP70 in different tissues of Milk fish (Chanoschanos) of Kaattuppalli Island, South East Coast, India. Chemosphere, 83: 415-421.

Sabae, Z.S. and Mohamed, A.S. (2015). Effect of Environmental Pollution on the Health of Tilapia spp. from Qarun Lake. Global Veterinaria 14: 304-328.

Saffran, K.; Cash. K.; Hallard, K.; Neary, B. and Wright, R. (2001). Canadian water quality guidelines for the protection of aquatic life CCME water Qual. Index 1 31-4

Shadrin, N.V.; El-Shabrawy, G.M.; Anufriieva, E.V.; Goher, M.E. and Ragab, E. (2016). Long-term changes of physicochemical parameters and benthos in Qarun Lake (Egypt): Can we make a correct forecast of ecosystem future? Knowl. Manag. Aquat. Ecosyst. 18

Tamasi, G. and Cini, R. (2004). Heavy metals in drinking waters from Mount Amiata (Tuscany, Italy). Possible risks from arsenic for public health in the Province of Siena Sci. Total Environ. 327 41-51

USEPA (1979). Development document for effluent limitations guidelines and standards for the gum and wood chemicals manufacturing. $250 \mathrm{p}$. https://nepis.epa.gov/Exe/ZyPDF.cgi/200180WL.PDF?Dockey=200180WL.PD $\mathrm{F}$

Vuori, R.M. (1995). Direct and indirect effects of iron on river ecosystem. Ann. Zool. Fenn. $23(3): 317-329$.

Williams, W.D. (2005). Environmental threats to salt lakes and the likely status of inland saline ecosystems in 2025. Environ Conserv. 29:154-67.

Wuana, R. A. and Okieimen, F. E. (2011). Heavy Metals in Contaminated Soils: A Review of Sources, Chemistry, Risks and Best Available Strategies for Remediation. ISRN Ecology. 2011, 1-20. doi:10.5402/2011/402647

Zhang, C.; Yu, Z.; Zeng, G.; Jiang, M.; Yang, Z.; Cui, F.; Zhu, M.; Shen, L.and Hu, L. (2014). Effects of sediment geochemical properties on heavy metal bioavailability. Environ. Int. 73, 270-281. doi.org/10.1016/j.envint.2014.08.010 